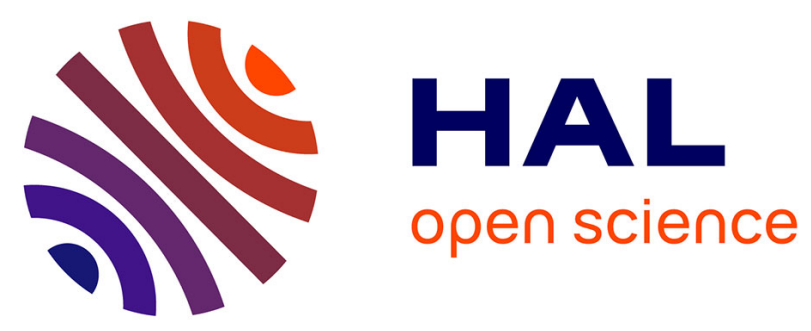

\title{
France 2072: Lifestyles at the core of carbon neutrality challenges
}

\author{
Ariane Millot, Rémy Doudard, Thomas Le Gallic, François Briens, Edi \\ Assoumou, Nadia Maïzi
}

\section{To cite this version:}

Ariane Millot, Rémy Doudard, Thomas Le Gallic, François Briens, Edi Assoumou, et al.. France 2072: Lifestyles at the core of carbon neutrality challenges. Giannakidis, G.; Karlsson, K.; Labriet, M.; Ó Gallachóir, B. Limiting Global Warming to Well Below $2{ }^{\circ} \mathrm{C}$ : Energy System Modelling and Policy Development, 64, Springer, 2018, Lecture Notes in Energy. hal-01896027

\section{HAL Id: hal-01896027 \\ https: / hal-mines-paristech.archives-ouvertes.fr/hal-01896027}

Submitted on 26 Oct 2018

HAL is a multi-disciplinary open access archive for the deposit and dissemination of scientific research documents, whether they are published or not. The documents may come from teaching and research institutions in France or abroad, or from public or private research centers.
L'archive ouverte pluridisciplinaire HAL, est destinée au dépôt et à la diffusion de documents scientifiques de niveau recherche, publiés ou non, émanant des établissements d'enseignement et de recherche français ou étrangers, des laboratoires publics ou privés. 


\title{
France 2072: Lifestyles at the core of carbon neutrality challenges
}

\author{
Ariane Millot, Rémy Doudard, Thomas Le Gallic, François Briens, Edi Assoumou \\ and Nadia Maïzi
}

Ariane Millot (corresponding author), Centre for applied Mathematics, MINES ParisTech, PSL Research University, Sophia Antipolis, France, ariane.millot@mines-paristech.fr

Rémy Doudard, Centre for applied Mathematics, MINES ParisTech, PSL Research University, Sophia Antipolis, France, remy.doudard@mines-paristech.fr

Thomas Le Gallic, Centre for applied Mathematics, MINES ParisTech, PSL Research University, Sophia Antipolis, France, thomas.le_gallic@mines-paristech.fr

François Briens, Centre for applied Mathematics, MINES ParisTech, PSL Research University, Sophia Antipolis, France, francois.briens@mines-paristech.fr

Edi Assoumou, Centre for applied Mathematics, MINES ParisTech, PSL Research University, Sophia Antipolis, France, edi.assoumou@mines-paristech.fr

Nadia Maïzi, Centre for applied Mathematics, MINES ParisTech, PSL Research University, Sophia

Antipolis, France, nadia.maizi@mines-paristech.fr

\begin{abstract}
In this chapter, we propose to explore the conditions under which a stringent target of $1.5^{\circ} \mathrm{C}$ - written into the Paris Agreement in December 2015 - may be fulfilled at a country level, France, while focusing on energy issues. The analysis horizon spans to 2072 in reference to the Club of Rome's 1972 Limits to Growth publication, 2072 being the neutral target. To this end, we explore the impact of two contrasting lifestyles for France: the first, named digital, represents an individualistic and technological society, whereas the second, named collective, depicts a society with strong social ties and cooperation between citizens. These scenarios are assessed through different models, each one representing a particular aspect: lifestyles, economy and technologies. While technology-oriented energy models usually omit or over-simplify the lifestyle dimension, the proposed approach gives a more coherent framework for the formulation of alternative demand levels. These demands for energy services enrich the scenariobuilding process and influence not only the economic system, but also the energy system. The digital society involves significant growth of both GDP and the unemployment rate, and does not result in carbon neutrality, whereas the collective society leads to smaller growth of GDP and a decrease in the unemployment rate, but
\end{abstract}


makes it possible to reach a nil carbon target. These results underline the leverage role of lifestyles in attaining carbon neutrality.

\section{Key messages}

- Policymakers must find a compromise between pathways that lead to economic growth (GDP) but make it impossible to reach a carbon neutrality target, such as a digital society, and pathways with lower GDP that enable reaching a carbon neutrality target, such as a more collective society.

- Policymakers must ensure consistency between the intended technology deployment and evolving lifestyles.

- Policymakers should make use of their ability to set up support measures in order to shift our habits toward more sobriety, especially in the transport sector.

- The TIMES models are relevant to study the impacts of lifestyle changes as they have to satisfy energy services demands that are linked to lifestyles.

\section{Introduction: Lifestyles as levers in the energy system transition}

\subsection{Carbon neutrality challenge}

Attempts to combat climate change have been the object of international negotiations for many years. The 2015 Paris Agreement set the specific target of: "holding the increase in the global average temperature to well below $2{ }^{\circ} \mathrm{C}$ above pre-industrial levels and pursuing efforts to limit the temperature increase to $1.5^{\circ} \mathrm{C}$ ". According to the Fifth IPCC's Assessment Report, to have a chance to respect this target, global emissions should be nil during the second half of the $21^{\text {st }}$ century. Some countries have already committed to attaining carbon neutrality, such as Norway by 2030 (Neslen 2016) and Sweden by 2045 (Bairstow 2017). In France, the current commitments are to reduce greenhouse gas emissions by $40 \%$ in 2030 and by $75 \%$ in 2050 compared with 1990 levels, but the question of neutrality is being debated, and the current minister for ecology Nicolas Hulot is pushing to adopt a neutral carbon target by 2050 (Ministry of Ecological and Solidarity Transition 2017). This would not actually mean nil emissions by 2050 because compensation mechanisms would be employed (international carbon credits, carbon sinks, etc.).

In order to evaluate to what extent France could respect the Paris Agreement, we have made a prospective analysis of the French energy system by exploring options aimed at reaching carbon neutrality in 2072 . This date allows us to go beyond the generally used but rapidly approaching 2050 horizon, to tackle the challenges impacting the second half of the century, as mentioned in the Paris Agreement. It also refers to the 1972 publication of the "Limits to Growth" report by the Club of Rome, which for the first time attempted to evaluate the long-term impacts of growth (on the environment, people, 
quality of life, etc.) and which provoked numerous debates on the sustainability of the development model of industrialized countries.

\subsection{Lifestyles in the framework of prospective analysis}

The energy system responds to a demand for energy services (heat, mobility, etc.) whose analysis is often restricted to techno-economic drivers and merits being extended. For example, the demand for mobility does not only depend on the price of gas or the means of transport (technology) used, but also on the choice of location of residence, the balance between real and virtual mobility (e.g. teleworking from home, e-commerce) and citizens' propensity to travel far from home. In other words, it depends on a set of determinants that are characteristic of lifestyle. Lifestyles can therefore constitute an analysis framework of demand for real-life services (Schipper et al 1989), which makes them important levers to tackle energy issues and climate change.

The role played by lifestyle was identified in 1987 by the authors of the Brundtland Report, who considered at the time that, "sustainable global development requires that those who are more affluent adopt life-styles within the planet's ecological means", stipulating, "in their use of energy, for example" (Brundtland et al 1987). The question of lifestyle has thus gradually drawn the attention of the scientific community, from the first studies of their connection to energy evoked in the analyses that followed the oil crises (Maréchal 1977; Leonard-Barton 1981; Dillman et al 1983) to their emphasis in the latest IPCC reports (IPCC 2007; IPCC 2014). The issue has thus motivated studies attempting to describe "sustainable" lifestyles (Druckman and Jackson 2010; Mont et al 2014; Neuvonen et al 2014), to identify ways to attain them (Tukker 2008), or to encourage citizens to adopt "low-carbon" lifestyles (Goodall 2010).

Although lifestyles have dramatically changed and diversified in the space of two or three generations, they are likely to be totally transformed during the 55 years that separate us from 2072, the target date of our study. Given the above, we have therefore decided to try to answer the following question: To what extent do lifestyles influence the energy system's capacity to achieve carbon neutrality? And amongst other, is a digital world compatible with the need to decarbonize the energy system, as usually thought?

\subsection{Soft linking of three models}

To answer this, we employ modeling to evaluate the long-term effects of lifestyles on the energy system. Along with this ambition to represent a complex system, we aim to take a complex approach that involves understanding the state of mutual dependence of several elements coming from a broad disciplinary spectrum.

Firstly, the question of evolving lifestyles requires characterizing and quantifying current and past practices to make it easier to integrate them into a prospective energy approach. Secondly, from these lifestyles we determine a configuration of the economy and production on which changes in final energy service demand are closely dependent. 
Lastly, we need to capture the complexity of the energy system through a detailed understanding of the diversity of technological chains to identify the best possible decarbonization avenues.

Prospective energy exercises traditionally focus on changes in technologies and the economy. This involves using partial equilibrium energy system models (like TIMES), sometimes coupled with macroeconomic models (known as top-down). We consider that it is impossible to tackle the issue of carbon neutrality and the conditions for achieving it without integrating a human dimension, which requires also considering lifestyles in the prospective analysis. Therefore, capturing in the most pertinent way possible the connections between lifestyles, economics and energy systems is an essential modeling concern. The TIMES model is especially relevant to study the impacts of lifestyle changes as the model has to satisfy energy services demands that are linked to lifestyles.

We therefore chose for this study to combine (by soft linking) three models each of which is devoted to one of the three "links" in the chain. In the following section, we describe the models used and the parameters that they integrate.

\section{Connecting economics, technique and society: the models}

Each of the models employed represents one of the three dimensions by which we can apprehend the overall system (i.e. technology, economy, and lifestyle). The way they are connected is represented in Fig. 1, with the liaison being established through the different demands. The model representing lifestyles simulates future individual demands for mobility, housing, and goods and services. These demands are used in the input data of a macroeconomic input-output analysis model representing the relationships between the different production sectors of the French economy, which evaluates the evolution in the activities of these different branches. The energy system model, i.e. the TIMES-FR model, is ultimately fed with the usage demands (demand for mobility and residential demand) taken from the model representing lifestyles, and with the demands for industry, agriculture, services and mobility of goods taken from the input-output model. In the next subsections we look in detail at how each of these models operates. 


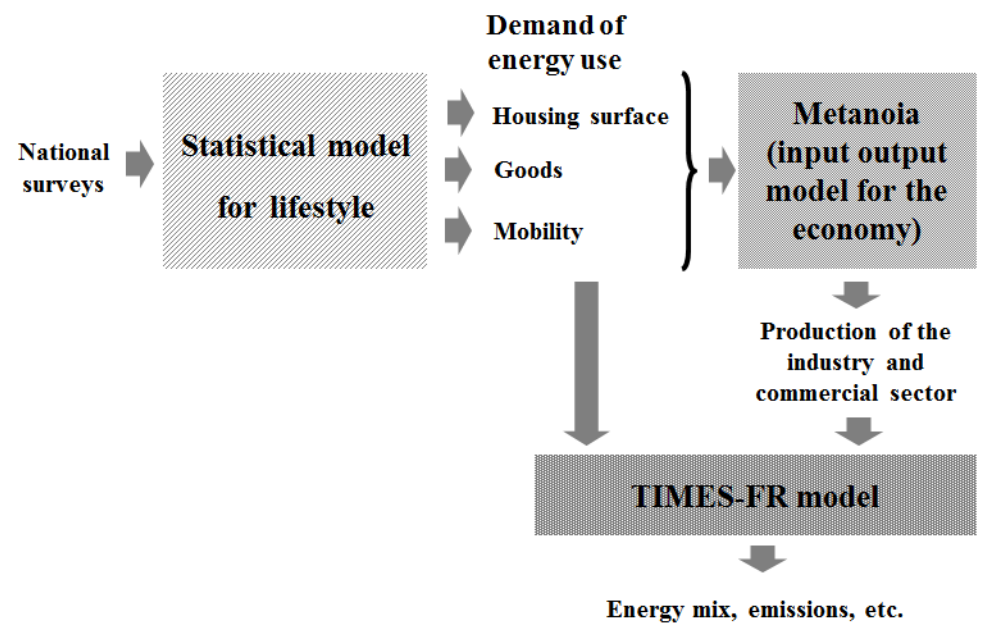

Fig. 1. Connections between the models used

\subsection{Reconstructing lifestyles}

The notion of lifestyle relates to multiple dimensions that can be extrapolated from the social practices of individuals and households. Although lifestyle is hard to define (Blok 2004), our use of the term refers to a certain set of key determinants, such as total housing surface area and total distance travelled per year. The simulation principle intuitively presented here is described in more detail in (Le Gallic et al 2017). The proposed model employs the combined data from four national surveys relating to these practices, i.e. the population census, the housing survey, the national survey on transport and journeys, and the household budget survey.

The simulation process employed by the model involves building up an image of the population, its lifestyles and energy uses based on a set of variables resulting from these surveys. The variables used relate to people's attributes (e.g. age, gender), lifestyle practices (e.g. residence location practices, cohabitation practices) and energy usage indicators. More precisely, the latter include the surface area of housing, the distances covered by distance section, and the volumes of purchases of certain goods, because they are at the origin of an indirect consumption of energy (cf. 3.1 Impact of lifestyle on energy uses).

Over a time period, the simulation involves enriching a simple demographic projection of the population (e.g. number of inhabitants by age) and progressively adding variables. The addition of variables thus highlights the correlations between variables existing in current or past surveys. These correlations take into account biological, economic, sociological and cultural phenomena. As an example, the surface area of housing per person currently depends on the location of the household (e.g. smaller dwellings in city centers because it's more expensive) or its size (due to pooling 
phenomena). Thus, if future households are less urban and more restricted because of changing lifestyles, the demand for housing surface area is likely to rise faster than the population, and this can be quantified by the simulation process.

The proposed representation ultimately relies on the identification of behavior patterns (e.g. mobility practices characteristic of people of a given age in a given situation; surface area of housing characteristic of households with a defined size and location). By considering these patterns as the structure of future behavior, we adopt the principle of mimicking behaviors. Underlying this is a hypothesis of reproduction of all or part of the social structures, psychological mechanisms, economic approaches, and the value systems in force.

\subsection{From lifestyle to economic impact: METANOIA Macroeconomic Model}

Assessing the environmental impacts of different lifestyles and social arrangements requires taking into account the specific configuration of the economy - especially the productive structure and processes - that they imply. For this purpose, we use METANOIA (Macro-Economic Tool for the Assessment of Narratives using OutputInput Analysis), a dynamic simulation macroeconomic model of the French economy, designed to run medium- to long-term scenarios. An in-depth description of this model can be found in (Briens 2015). This model has been built using public data only essentially from the national statistics bodies, INSEE and EUROSTAT. It features a sectorial disaggregation of the economy into 37 branches (e.g. agriculture, health, transport, construction, etc.), and various specific modules: demography (cohort model), demand for goods and services, residential sector, transport, agriculture, capital stocks (different types of productive assets are considered: dwellings, machinery, transport equipment, intangible fixed assets, etc.), foreign exchanges, employment, fiscal apparatus and the public administration budget (Fig. 2). For the sake of simplicity, there is no explicit monetary sector in our model. 


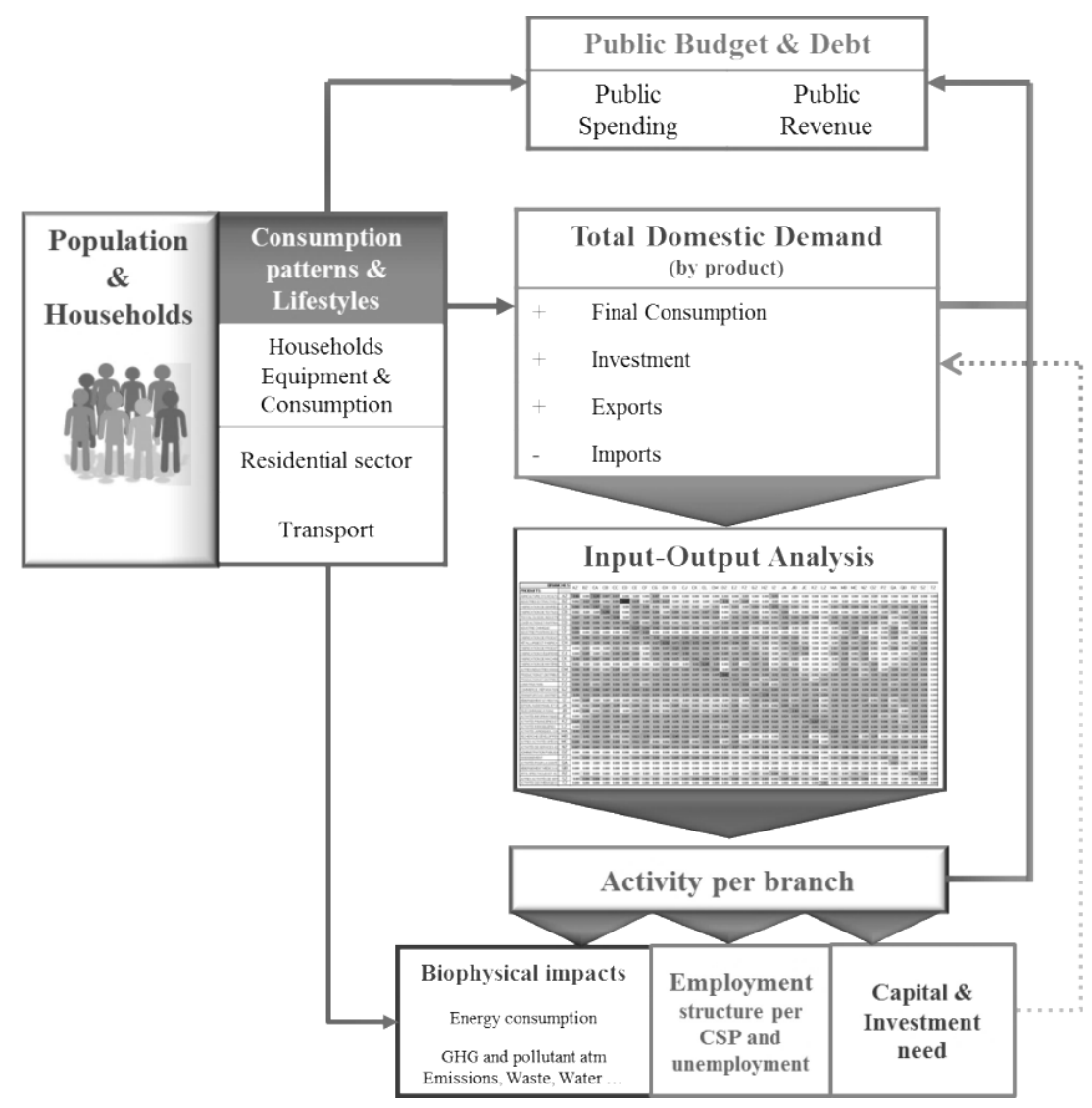

Fig. 2. Simplified structure of METANOIA

In a nutshell, sectorial final demand stems mostly from exogenous hypotheses aiming at reflecting changes in consumption patterns, lifestyles, and the social organization, and expressed in terms of evolution of household demand for different goods and services, their mobility and housing choices, etc. This final demand "drives" the evolution of the production of the different branches, which is determined using input-output analysis, so as to take into account the complex direct and indirect relationships and interdependencies between the various branches of the economy (Briens 2015). Using input-output analysis makes it possible to define the production of the different branches of the economy that corresponds to given levels of final demand, based on a matrix of technical coefficients. In order to reflect technical changes in the production processes, the technical coefficients of the input-output table may evolve according to exogenous hypotheses. For each branch, the production level in turn determines the need for investment or the amount of labor required on the basis of assumptions regarding the 
evolution of labor, capital, energy and emissions intensities in that branch. Socioeconomic outcomes, including employment and unemployment, public budget balance and debt, depend on policy choices (these can include working time, public expenditure, fiscal and redistributive policies).

\subsection{Integrating economics and lifestyle into the French energy system: TIMES-FR model}

The TIMES-FR model initiated in (Assoumou 2006) represents the French energy system. This bottom-up techno-economic model is based on an optimality paradigm: by minimizing the total discounted cost of the energy system over the considered horizon (we applied a social discount rate of $4 \%$ ), it selects technologies that can satisfy energy service demands. Each sector of the energy system features a detailed representation of the technologies available and the associated energy values, along with their technical and economic characteristics, availability date for new technologies, and deployment potential (e.g. for wind or solar). Energy service demands include demands from the residential and tertiary sectors (heating, cooking, hot water and specific electricity), disaggregated demands for mobility of goods and passengers depending on the transport mode (road, rail, air or river), and lastly demands from agriculture and industry. As part of the recalibration of the model's reference year (now 2014), a breakdown of demands from industry and the tertiary sector was introduced to improve the association with the METANOIA model: 21 sectors in industry and 8 branches in the tertiary sector. The agriculture sector was also subdivided, including a demand for tractors and another for buildings. This more detailed disaggregation than in standard models means that we can introduce means to decarbonize this sector, for example oil substitutes used for tractors (gas, biodiesel, electricity).

\section{What are the levers for carbon neutrality?}

In this section, and in order to illustrate how much lifestyle weighs in the overall balance, we have chosen to explore the consequences of two contrasting lifestyle scenarios on the economy and the energy system thanks to the breakdown of the models and approaches described above. The starting point of the exercise therefore involves outlining two lifestyle evolution scenarios based on a set of coherent hypotheses.

The first, entitled "digital society" reflects this trend: "In this more individualistic and technological society, people are motivated by a desire for personal achievement and long life."

The second is called "collective society" and describes alternative aspirations: "In this society organized around social connections and cooperation, people are motivated by a desire to be - and do - with others." 


\subsection{Impact of lifestyles on energy uses}

\subsubsection{Hypotheses for the lifestyles model}

The hypotheses attributed to different dimensions of lifestyle are briefly described in Table 1.

Table 1. Overview of hypotheses from both scenarios by lifestyle dimension

\begin{tabular}{|c|c|c|}
\hline DIMENSIONS & DIGITAL SOCIETY & COLLECTIVE SOCIETY \\
\hline Demography & $\begin{array}{c}+18 \% \\
\text { Higher life expectancy, } \\
\text { lower birth rate }\end{array}$ & $\begin{array}{c}18 \% \\
\text { Continuation of current trends } \\
\text { (inc. aging of the population) }\end{array}$ \\
\hline Cohabitation practices & More single households & $\begin{array}{c}\text { Development of shared forms } \\
\text { of housing }\end{array}$ \\
\hline $\begin{array}{c}\text { Relationship with } \\
\text { technologies }\end{array}$ & Higher equipment level & $\begin{array}{c}\text { Maintenance of current } \\
\text { practices }\end{array}$ \\
\hline $\begin{array}{l}\text { Mobility practices and } \\
\text { relationship to space }\end{array}$ & $\begin{array}{l}\text { More virtual activities } \\
\text { (e.g. teleworking) }\end{array}$ & Contraction of activity area \\
\hline Work attitude & $\begin{array}{l}\text { Greater place of work in } \\
\text { society }\end{array}$ & $\begin{array}{l}\text { Reduced place of work in time } \\
\text { organization }\end{array}$ \\
\hline Location of dwelling & $\begin{array}{l}\text { Preference for urban } \\
\text { centers in cities }\end{array}$ & $\begin{array}{l}\text { Reduction in semi-urban areas } \\
\text { to the benefit of urban areas }\end{array}$ \\
\hline $\begin{array}{l}\text { Living standard, } \\
\text { income and } \\
\text { distribution }\end{array}$ & Higher living standard & $\begin{array}{l}\text { Drop in the number of } \\
\text { households with high and low } \\
\text { incomes }\end{array}$ \\
\hline $\begin{array}{l}\text { Tourism and leisure } \\
\text { travel practices }\end{array}$ & $\begin{array}{l}\text { Development of long- } \\
\text { distance destinations }\end{array}$ & $\begin{array}{c}\text { Development of local } \\
\text { destinations }\end{array}$ \\
\hline
\end{tabular}

\subsubsection{Results of the lifestyles model}

The simulations of the two scenarios developed provide a quantified glimpse of the influence of future lifestyles on energy uses in 2072 and very contrasting results depending on the options selected.

Regarding the uses of the residential sector, the extent of the challenge of a transition towards a low-carbon housing is very different in the two scenarios. Thus, the housing surface area to be heated and cooled slightly increases in the "collective society" scenario $(+10 \%$ compared to currently) and increases much more in the "digital society" scenario $(+34 \%)$. The variations are similar for specific electricity and hot water uses. These simulations show to what extent future cohabitation practices and future location 
choices will impact the "quantity" of residential energy uses to satisfy. The increase in the relative proportion of shared housing solutions on the one hand, and the proportion of collective housing solutions on the other, can help reduce the housing surface to be heated and cooled, and to be renovated and built. Thus the "cost" of achieving energy performance for the housing stock could be lower.

Simulations of the demand for goods in 2072 also showed significant differences between scenarios, which varied depending on the type of good considered: between $+4 \%$ and $+134 \%$ for the "digital society" scenario compared to the "collective society" scenario (Fig. 3). They also shed light on certain effects connected to pooling facilities and in particular the changing relationship to technologies.

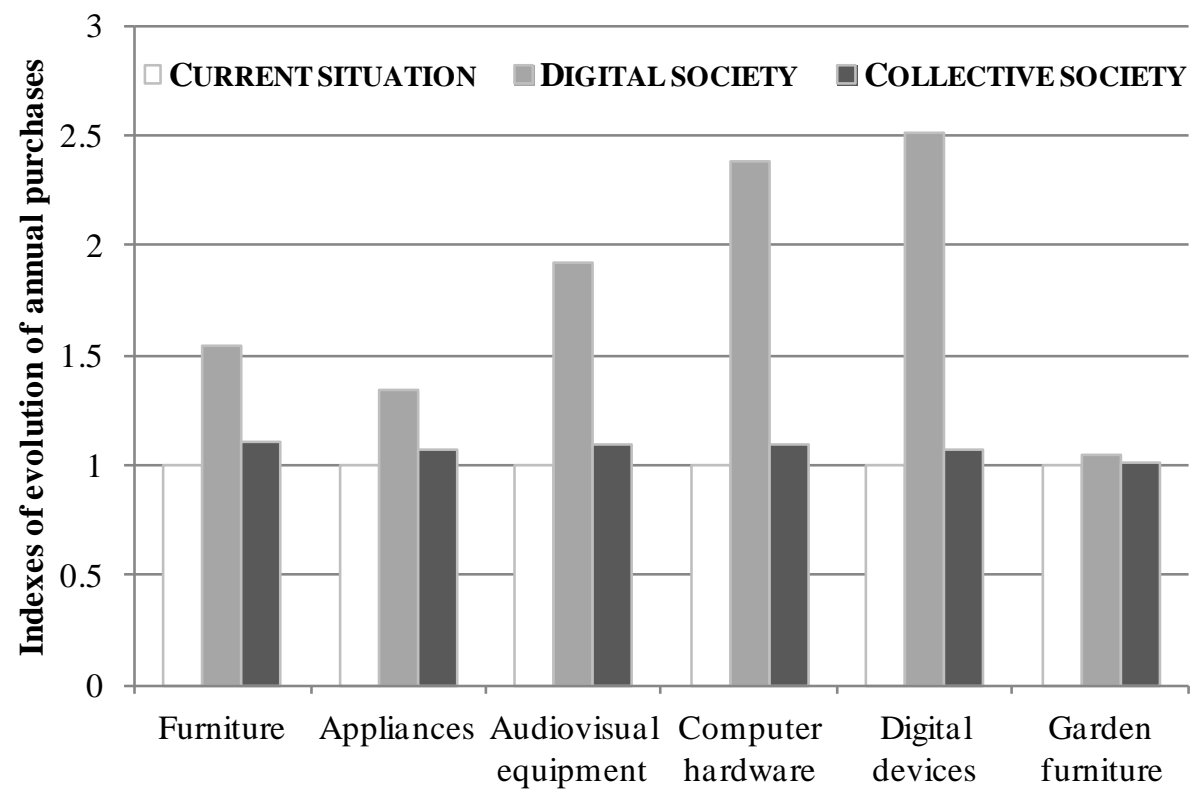

Fig. 3. Consumption of six types of durable goods for the two scenarios and the current situation (indexes of evolution of annual purchases)

Lastly, the simulations of uses connected to mobility produced marked contrasts, both for local mobility and long-distance mobility. The "collective society" scenario led to a $35 \%$ drop in distances covered annually for daily journeys due to a contraction of the living area and a reorganization of activities (Fig. 4). However, the number of journeys per person remains practically identical to the current situation in this scenario. An 11\% drop in distances covered is also simulated for the "digital society" scenario, this time resulting mainly from a decrease in the number of journeys made. In fact, part of the actual mobility is substituted by virtual mobility (e.g. teleworking from home). Nevertheless, the model's capacity to take into account the systemic impacts of this kind 
of hypothesis remains limited (e.g. effects of the transfer of personal mobility connected to purchases towards delivery of goods, rebound effects of teleworking, impact on domestic energy consumption of an increased presence in the home).

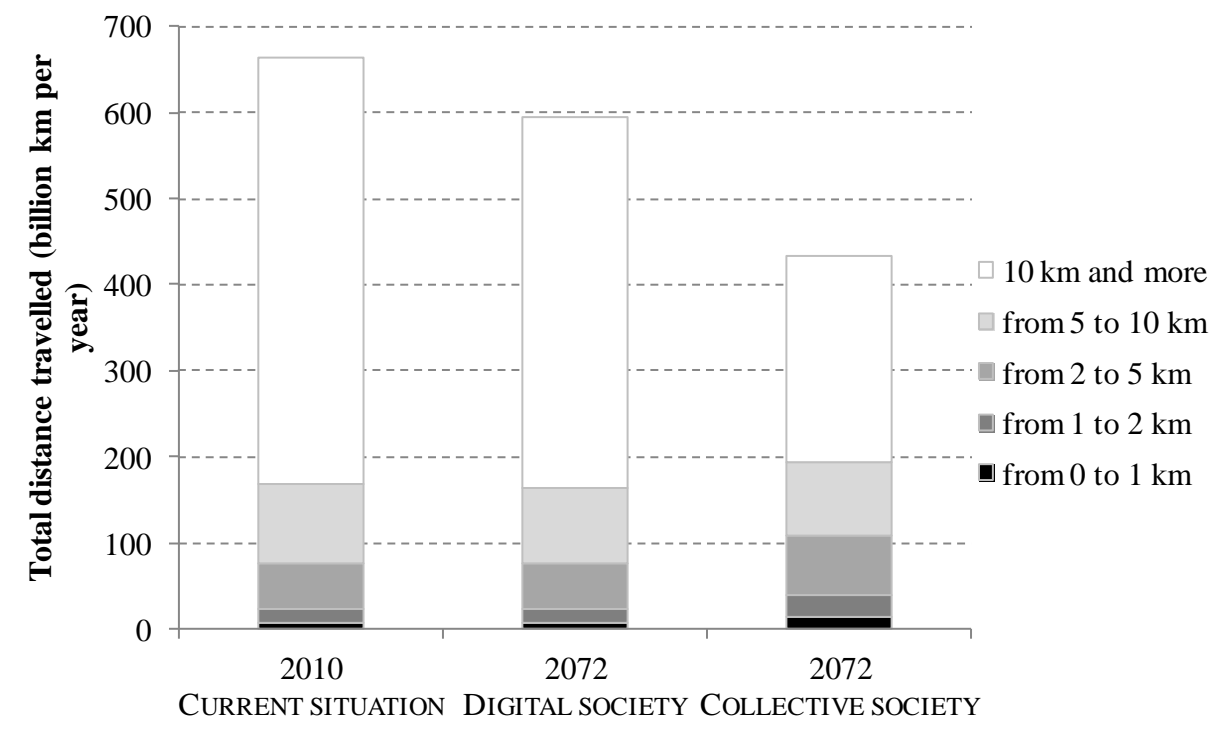

Fig. 4. Short-distance mobility demand under the three scenarios in 2072

For long-distance mobility, changes of a cultural nature were explored and produced a broad range of results (from $-34 \%$ to $+115 \%$ compared to the current situation). These simulations of long-distance mobility indicate on the one hand the decisive impact of lifestyle choices on mobility demand, and on the other hand the antagonisms that can emerge between local and long-distance mobility. These antagonistic evolutions introduced into the "digital society" scenario show that a significant reduction in personal local mobility can be more than compensated by more intensive long-distance mobility practices.

\subsection{Impacts of lifestyles on the economic system}

\subsubsection{Hypotheses for the input-output analysis}

Concerning the macroeconomic modeling, in both of the scenarios studied, the hypotheses concerning the households' changing consumption of goods, housing surface areas and mobility were defined from the results of the model's lifestyle simulations. Other hypotheses concerning the evolution of the population's activity rate, hourly productivity, the speed of obsolescence of capital (life expectancy and scrappage functions for assets), the development of external commerce, and the evolution of 
technical coefficients on the input-output table were chosen exogenously in order to coherently reflect the social transition and the lifestyles considered. Table 2 gives a succinct overview of the different hypotheses employed.

Table 2. Hypotheses for the METANOIA model

\begin{tabular}{|c|c|c|c|}
\hline \multicolumn{2}{|c|}{ DIMENSIONS } & DIGITAL SOCIETY & COLLECTIVE SOCIETY \\
\hline \multirow{3}{*}{$\begin{array}{l}\text { Employ- } \\
\text { ment }\end{array}$} & Labor Force & $\begin{array}{l}\text { Extension by } 10 \text { years of } \\
\text { the retirement age }\end{array}$ & Activity rate unchanged \\
\hline & $\begin{array}{c}\text { Annual } \\
\text { productivity } \\
\text { gains }\end{array}$ & Divided by 3 by 2070 & Divided by 5 by 2070 \\
\hline & $\begin{array}{l}\text { Working time } \\
\text { policies }\end{array}$ & No change & $\begin{array}{l}\text { Annual work duration: } \\
-20 \% \text { on average }\end{array}$ \\
\hline \multicolumn{2}{|c|}{ Capital stocks } & $\begin{array}{l}\text { Lifespan of capital reduced } \\
\text { in all sectors: }-20 \% \text { for } \\
\text { computing, software and } \\
\text { machines \& equipment by } \\
2072 \text { (obsolescence through } \\
\text { rapid innovation), and }-10 \% \\
\text { for the remainder }\end{array}$ & $\begin{array}{l}\text { Lifespan of capital increased } \\
\text { in some sectors: }+20 \% \text { for } \\
\text { computing, software and } \\
\text { machines \& equipment, and } \\
\text { vehicles by } 2072 \text {, and }+5 \% \\
\text { for non-residential buildings }\end{array}$ \\
\hline \multirow[t]{2}{*}{$\begin{array}{c}\text { Foreign } \\
\text { Trade }\end{array}$} & Imports & $\begin{array}{l}\text { Slight increase in imports: } \\
\text { from }+5 \% \text { to }+20 \% \text { for } \\
\text { heavy industry (extractive } \\
\text { industry, metallurgy, etc.) }\end{array}$ & $\begin{array}{l}\text { Relocation: Drop in imports } \\
\text { of } 30 \% \text { for agriculture and } \\
10 \% \text { for most industrial } \\
\text { products }\end{array}$ \\
\hline & Exports & $\begin{array}{l}\text { Evolution of exports in } \\
\text { proportion to imports }\end{array}$ & $\begin{array}{l}\text { Evolution of exports in } \\
\text { proportion to imports }\end{array}$ \\
\hline \multirow[t]{2}{*}{ Transport } & $\begin{array}{l}\text { Modal share } \\
\text { of passenger } \\
\text { transportation }\end{array}$ & No change & $\begin{array}{l}\text { Increase in walking and } \\
\text { cycling for short distances, } \\
\text { collective transport (public } \\
\text { transport and trains) for } \\
\text { middle and long distances }\end{array}$ \\
\hline & Freight & No change & $\begin{array}{l}\text { Transfer of } 10 \% \text { of road } \\
\text { transport to rail }\end{array}$ \\
\hline
\end{tabular}




\begin{tabular}{|c|c|c|}
\hline \multirow{3}{*}{ Household consumption } & $\begin{array}{c}\text { Increased consumption in } \\
\text { some branches (housing, } \\
\text { catering, health, leisure } \\
\text { activities, social housing) } \\
\text { and shorter lifespan for } \\
\text { equipment }\end{array}$ & $\begin{array}{c}\text { Drop in consumption or } \\
\text { moderate increase in most } \\
\text { branches and longer lifespan } \\
\text { for equipment }\end{array}$ \\
\hline
\end{tabular}

\subsubsection{Results of the METANOIA model}

The simulation of these two scenarios in the METANOIA model gives contrasting results, in particular in terms of total final demand split between each of the 37 branches of the economy. This goes up by $62 \%$ for the "digital society" scenario compared to $8 \%$ for the "collective society" scenario from 2014 to 2072 (Fig. 5). These evolutions are particularly marked in the "digital society" scenario for the branches connected to computing (manufacture of equipment or telecommunications), and branches connected to health, while for the "collective society" scenario, the demand goes down in the branches of computer equipment manufacture, clothing, and branches involving vehicle construction.

These changes in demand logically translate into production indicators (Fig. 5): the "digital society" scenario, which is devised to reflect a more individualistic society that consumes high quantities of goods and services, leads to a 73\% increase in GDP from 2014 to 2072 (split between the industry and tertiary branches, in particular transport, where activity doubles), compared to $9 \%$ for the "collective society" scenario, which corresponds to more sober lifestyles and more collective consumption patterns. In this latter scenario, most branches of the economy undergo moderate growth in their activity and we see a drop in the activity of branches connected to transport (manufacture of equipment and transport of goods).

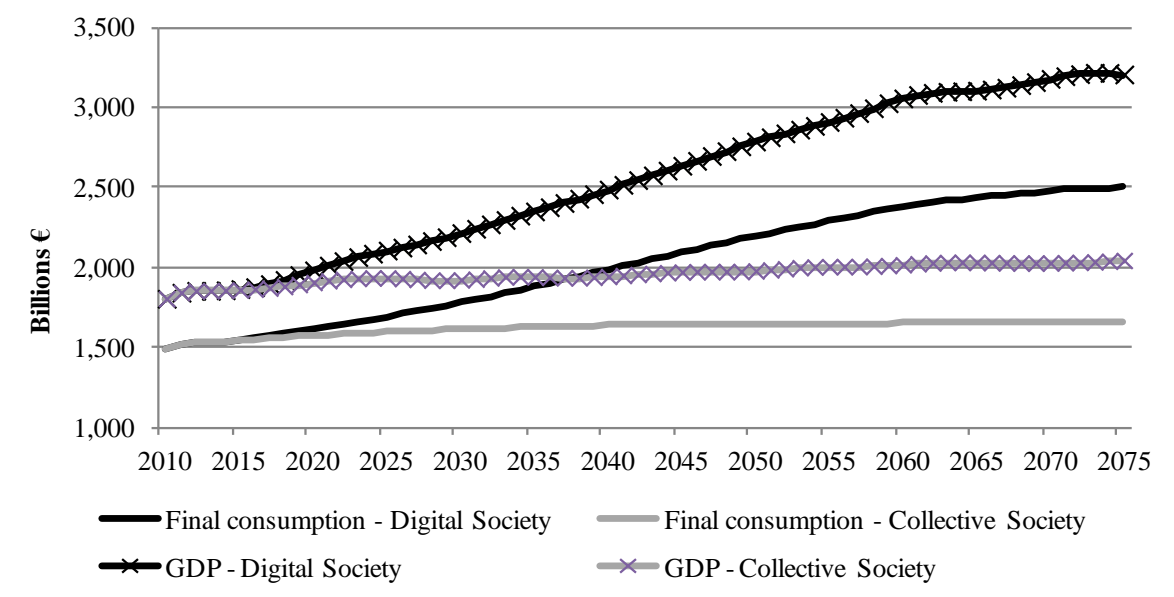

Fig. 5. Evolution of GDP and final consumption 
Looking at the evolution of indicators connected to employment, we observe that in the "digital society" scenario, despite an increase in the total number of jobs, unemployment gets worse, due to the greater duration of work and active life (postponement of exit from the labor market), and improved productivity (Fig. 6). In the "collective society" scenario, the increase in total employment is moderate, while unemployment reaches very low levels, attaining 3\% in 2072 (Fig. 6).

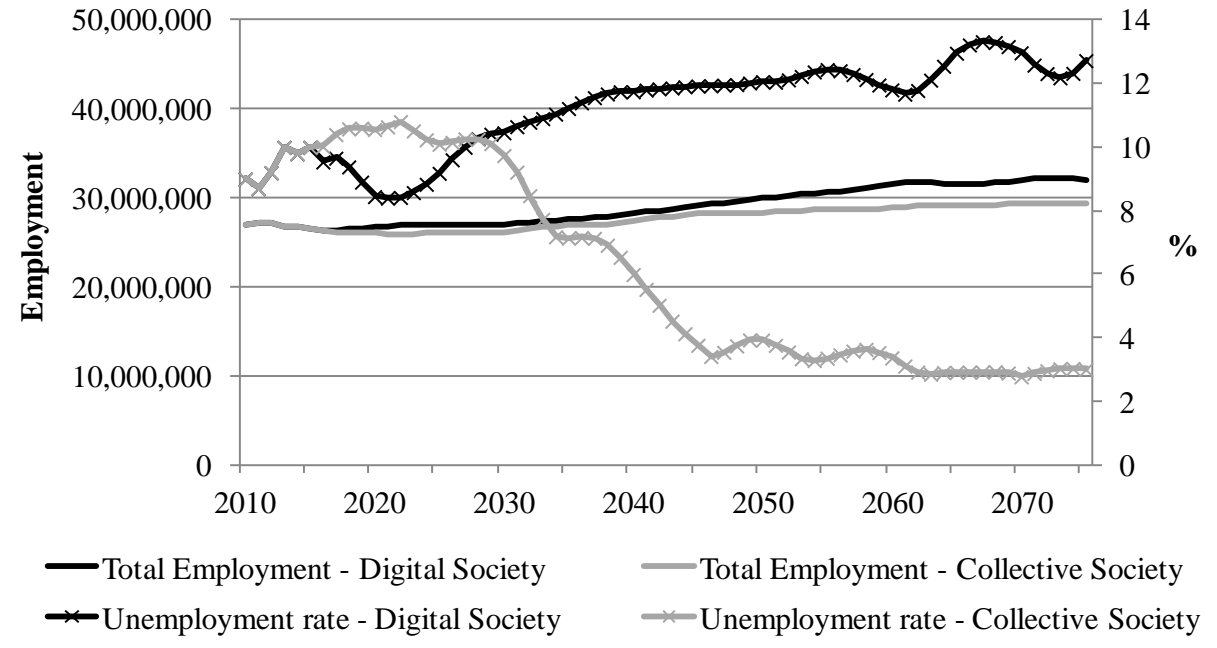

Fig. 6. Total employment and unemployment rate

\subsection{Impacts of lifestyles on the energy system}

In this section, we discuss the energy system's capacity to satisfy the demand for services that results from both lifestyle scenarios described above under the constraint to reach $\mathrm{CO}_{2}$ neutrality by 2072 (we consider only $\mathrm{CO}_{2}$ emissions in this study and no other GHGs).

\subsubsection{Influence of lifestyles on the marginal cost of $\mathrm{CO}_{2}$}

In order to evaluate the efforts required to reach the carbon-neutral objective, we employ as an indicator the marginal cost of the carbon constraint, which translates the impact of an additional one-ton reduction in $\mathrm{CO}_{2}$ on the total discounted cost of the system (thus in some ways translating the state of tension in which our system finds itself under constraint). The analysis of this indicator highlights (1) a non-linearity of the effort made to decarbonize in both scenarios and (2) the essential weight of lifestyles vis-à-vis the system's propensity to reach carbon neutrality.

The evolution patterns of the marginal cost are similar in both scenarios (Fig. 7); they translate a non-linearity between the decarbonization trajectory and the marginal cost of the $\mathrm{CO}_{2}$ constraint. Up to 2035, the state of constraint is low, while emissions have 
already gone down by $40 \%$ compared to 1990 . After this date, there is a strong upward effect due to the zero-emission target especially in the digital society scenario.

The values of the marginal cost shown by both scenarios are on the other hand very different, and this difference increases as it approaches the 2072 horizon (Fig. 7). At this date, the marginal cost for the "digital society" scenario reaches a value 700 times higher than for the "collective society" scenario. In fact, in the "digital society" scenario, the system finds itself in an "over-constrained" state. To achieve carbon neutrality, materials and energy are imported by the system at a very high price. Only the introduction of a hypothesis of elastic demand, which would illustrate consumers' propensity to adjust their demand for energy services in line with the marginal cost of energy (compared to a reference case with no carbon constraint) brings about a relaxation in tensions in the modeled system, and the return to a lower $\mathrm{CO}_{2}$ marginal cost, but therefore meaning changes in consumption behaviors ... and thus lifestyles.

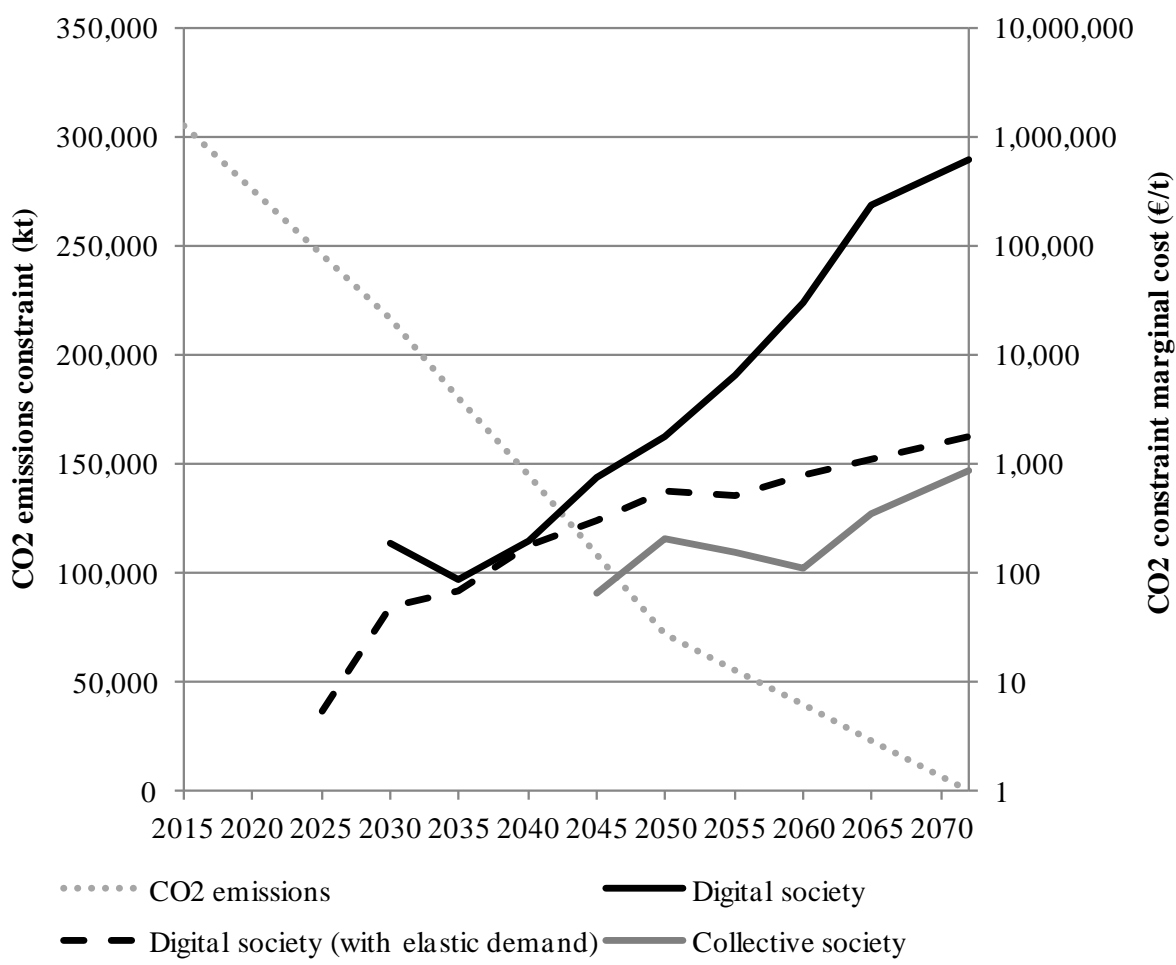

Fig. 7. $\mathrm{CO} 2$ emissions constraint and marginal cost of the $\mathrm{CO} 2$ constraint

\subsubsection{Influence of lifestyles on final energy consumption}

A shift towards more sober lifestyles, for example in the spirit of a "collective society" scenario, thus appears to be crucial for the transition towards an energy system 
that has less of an impact on the environment. Beyond the significant reduction of final energy consumption in the collective scenario (-29\% between 2014 and 2072), the results show that the largest drop occurs in the transport sector (Fig. 8). Moreover, final energy consumption in this sector is reduced by $40 \%$ compared to the digital society scenario. Lifestyle changes can thus significantly influence the transport sector.

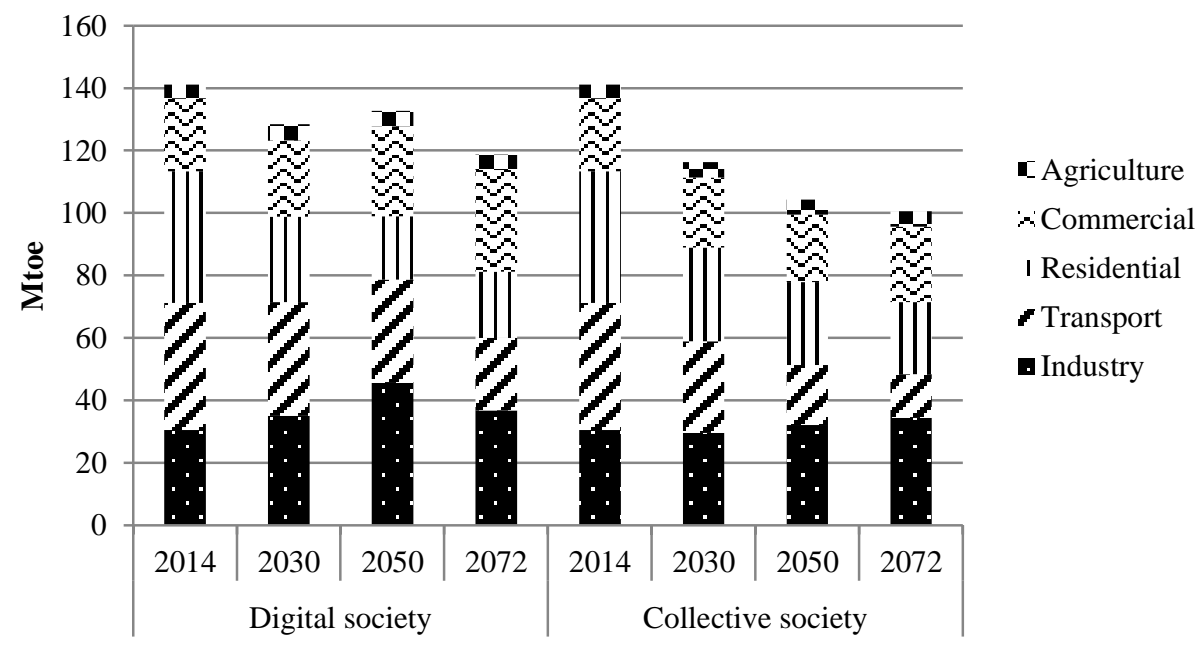

Fig. 8. Final energy consumption by sector

Moreover, the results show that the optimal configuration of the energy system associated with this scenario does not favor a single vector, but rather a multi-energy configuration in which we observe a varied range of technological solutions solicited to decarbonize the system (Fig. 9Fig. 9). 


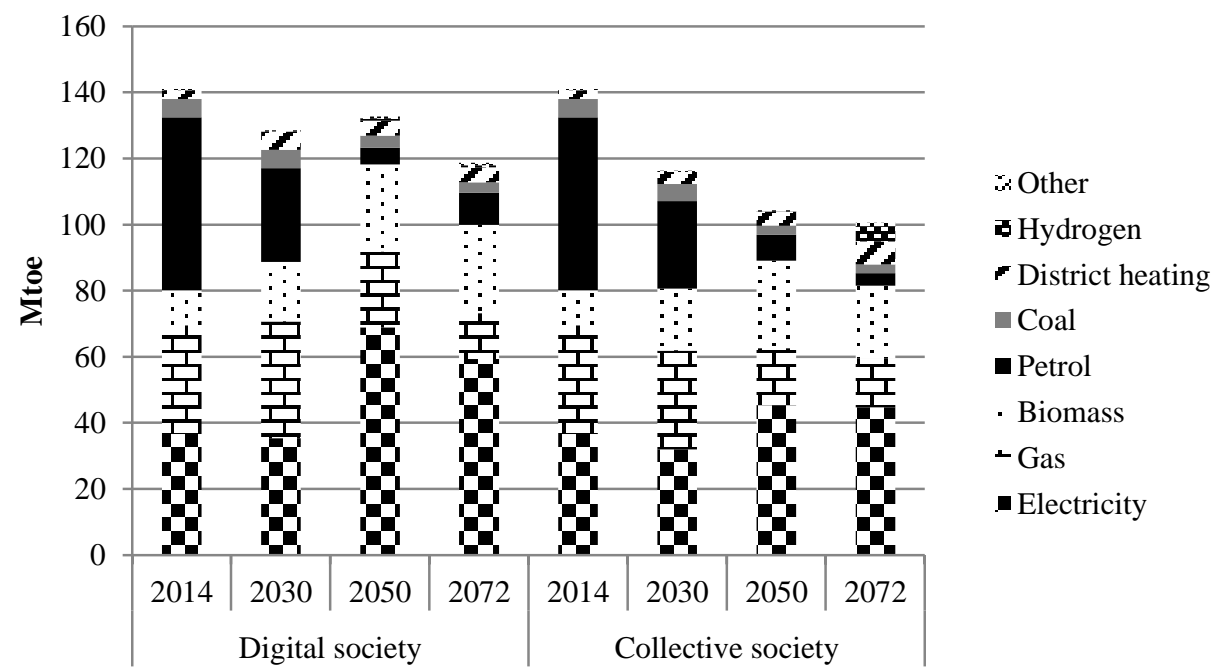

Fig. 9. Energy mix in final energy consumption

A significant reduction in emissions thus inevitably involves considerable technological substitutions: this raises the questions of technical feasibility and social acceptability, like for example the use of CCS on a wide scale in the industrial and power sector up to $50,000 \mathrm{ktCO}_{2} /$ year in the "collective society" scenario and up to $60,000 \mathrm{ktCO}_{2} /$ year in the "digital society".

\section{Conclusion}

Numerous appeals are currently being made to move towards a more digital world in which the interactions between digital transition and energy transition will make it easier to achieve a decarbonized society. The "digital society" scenario that we have described was devised with this in mind, whereas the "collective society" scenario fits in more with grassroots/bottom-up attitudes of degrowth. While the energy transition is often described as expensive, difficult and even unlikely, the digital transition receives a more enthusiastic reaction from economic and public stakeholders, who see in it a means to guarantee the road to growth. But is a digital world compatible with decarbonizing the energy system?

Our study shows that a digital society-type scenario makes the attainment of carbon neutrality unrealistic, even with the deployment of new technologies and deep changes in the energy mix. This result is subject to the availability of the decarbonization means currently available in our model and to the deployment of incentive policies to accompany the phasing-out of conventional technologies. In brief, technological 
evolutions and the move towards a digital society would not be sufficient to reach the target of carbon neutrality.

Based on this observation, we can either hope for the emergence of disruptive technologies (e.g. nuclear fusion) leading to rapid decarbonization, or reflect on social choices and lifestyles compatible with a carbon-neutral objective. In our exercise, attaining carbon neutrality is only possible if lifestyles change significantly compared to present trends, coupled with technological change.

As a digital society leads to higher GDP growth than a collective society, policymakers have to find a compromise between these pathways in order to enable a carbon-neutral target. But moving away from a collective scenario pathway only makes a carbon neutrality target more difficult to achieve. Policymakers must also ensure consistency between the intended technology deployment and the evolution of lifestyles. The societal organization stemming from a digital society will amplify the impacts of digitalization (more long-distance trips, more individual houses, more datacenters, etc.), unlike a collective society. Finally, the transport sector appears to be one of the key sectors for decarbonisation and can particularly be influenced by lifestyle changes. Since existing urban plans and transport infrastructures are closely linked to mobility habits, significant state support is vital in order to counter the inertia of this system.

To conclude, let's remind that the target to reach neutrality in France by 2072 may not be sufficient for the $1.5^{\circ} \mathrm{C}$ scenario as industrialized countries should preferably attain this level by 2050 . Thus the pathways introduced in this chapter would need to be even more ambitious to reach a target well below $2^{\circ} \mathrm{C}$. However, they highlight the main hurdles to reaching neutrality that would be exacerbated by an earlier target date.

As far back as 1972, the authors of the "Limits to Growth" report launched an alert on the non-sustainability of our system, and called for a deep-seated change in our development mode and thus society. As we declare the need to limit climate change, in order to achieve carbon neutrality it seems necessary to act not just on the deployment of decarbonized technologies, but on our lifestyles, which we should urgently question, and collectively redirect. This could constitute a brake as much as a lever in the energy transition.

\section{References}

Assoumou E (2006) Modélisation MARKAL pour la planification énergétique long terme dans le contexte français. École Nationale Supérieure des Mines de Paris

Bairstow J (2017) Sweden says it will go 'carbon neutral by 2045.' In: Energy Live News - Energy Made Easy -. http://www.energylivenews.com/2017/06/20/sweden-says-it-will-go-carbonneutral-by-2045/. Accessed 17 Aug 2017 
Blok K (2004) Lifestyles and Energy. In: Cleveland CJ (ed) Encyclopedia of Energy. Elsevier, New York, pp 655-662

Briens F (2015) La Décroissance au prisme de la modélisation prospective: Exploration macroéconomique d'une alternative paradigmatique. Phdthesis, Ecole Nationale Supérieure des Mines de Paris

Brundtland G, Khalid M, Agnelli S, Al-Athel S, Chidzero B, Fadika L, Hauff V, Lang I, Shijun M, Morino de Botero M, Singh M, Okita S, And Others (1987) Our Common Future ('Brundtland report')

Dillman DA, Rosa EA, Dillman JJ (1983) Lifestyle and home energy conservation in the United States: the poor accept lifestyle cutbacks while the wealthy invest in conservation. J Econ Psychol 3:299-315 . doi: 10.1016/0167-4870(83)90008-9

Druckman A, Jackson T (2010) The bare necessities: How much household carbon do we really need? Ecol Econ 69:1794-1804 . doi: 10.1016/j.ecolecon.2010.04.018

Goodall C (2010) How to live a low-carbon life: the individual's guide to stopping climate change, 2. ed., fully updated. Earthscan, London

IPCC (2007) Climate Change 2007: Synthesis Report. Contribution of Working Groups I, II and III to the Fourth Assessment Report of the Intergovernmental Panel on Climate Change, IPCC. Geneva, Switzerland

IPCC (2014) Climate change 2014: synthesis report. Contribution of Working Groups I, II and III to the Fifth Assessment Report of the Intergovernmental Panel on Climate Change, IPCC. Intergovernmental Panel on Climate Change, Geneva, Switzerland

Le Gallic T, Assoumou E, Maïzi N (2017) Future demand for energy services through a quantitative approach of lifestyles. Energy. doi: 10.1016/j.energy.2017.07.065

Leonard-Barton D (1981) Voluntary Simplicity Lifestyles and Energy Conservation. J Consum Res 8:243 . doi: $10.1086 / 208861$

Maréchal P (1977) Crise de l'énergie et évolution des modes de vie. CREDOC

Meadows DH, Meadows DL, Randers J, Behrens III WW (1972) The limits to growth: a report for the Club of Rome's Project on the Predicament of Mankind, 2. ed. Universe Books, New York

Ministère de la transition écologique et solidaire (2017) Plan Climat 
Mont O, Neuvonen A, Lähteenoja S (2014) Sustainable lifestyles 2050: stakeholder visions, emerging practices and future research. J Clean Prod 63:24-32 . doi: 10.1016/j.jclepro.2013.09.007

Neslen A (2016) Norway pledges to become climate neutral by 2030. The Guardian

Neuvonen A, Kaskinen T, Leppänen J, Lähteenoja S, Mokka R, Ritola M (2014) Low-carbon futures and sustainable lifestyles: A backcasting scenario approach. Futures 58:66-76 . doi: 10.1016/j.futures.2014.01.004

Schipper L, Bartlett S, Hawk D, Vine E (1989) Linking Life-Styles and Energy Use: A Matter of Time? Annu Rev Energy 14:273-320 . doi: 10.1146/annurev.eg.14.110189.001421

Tukker A (ed) (2008) Perspectives on radical changes to sustainable consumption and production. Greenleaf, Sheffield 